Abstracta Iranica

Revue bibliographique pour le domaine irano-aryen

Volume 37-38-39 | 2018

Comptes rendus des publications de 2014-2016

\title{
Annick Payne, Jorit Wintjes. Lords of Asia Minor. An Introduction to the Lydians
}

\section{Astrid Nunn}

\section{(2) OpenEdition}

1 Journals

\section{Édition électronique}

URL : http://journals.openedition.org/abstractairanica/46227

DOI : 10.4000/abstractairanica.46227

ISBN : 1961-960X

ISSN : 1961-960X

Éditeur :

CNRS (UMR 7528 Mondes iraniens et indiens), Éditions de l'IFRI

Référence électronique

Astrid Nunn, «Annick Payne, Jorit Wintjes. Lords of Asia Minor. An Introduction to the Lydians »,

Abstracta Iranica [En ligne], Volume 37-38-39 | 2018, document 76, mis en ligne le 30 décembre 2018, consulté le 27 septembre 2020. URL : http://journals.openedition.org/abstractairanica/46227 ; DOI : https://doi.org/10.4000/abstractairanica.46227

Ce document a été généré automatiquement le 27 septembre 2020

Tous droits réservés 


\title{
Annick Payne, Jorit Wintjes. Lords of Asia Minor. An Introduction to the Lydians
}

\author{
Astrid Nunn
}

\section{RÉFÉRENCE}

Annick Payne, Jorit Wintjes. Lords of Asia Minor. An Introduction to the Lydians. Wiesbaden: Harrassowitz Verlag, 2016, x+145 p. (Philippika, vol. 93)

1 La Lydie est restée "populaire" grâce à Crésus (?-547/6 av. J.-C.), peut-être aussi car elle fascinait les Grecs. Les sources historiques restent néanmoins difficiles, et notre connaissance des cités est essentiellement limitée à Sardes. Ceci est la raison pour laquelle les deux auteurs ont présenté une monographie introductive. Celle-ci est divisée en six chapitres sur l'histoire (surtout du $8^{\text {ème }}$ s. av.n. è. - 334 av. J.-C.), Sardes et l'archéologie de la Lydie, la langue lydienne, les inscriptions lydiennes, la civilisation lydienne et la réception de ce royaume depuis Crésus.

2 Je ne peux juger en détail de l'exactitude des développements linguistiques, illustrés par des tableaux et des cartes. Toutefois aucune fouille, ni aucun objet archéologique (sauf les monnaies) n'est illustré. L'impact des achéménides n'est pas traité. Ce résumé n'est en fin de compte pas exhaustif et constitue une source plus appropriée pour historiens et philologues que pour les archéologues. 


\section{AUTEURS}

\section{ASTRID NUNN}

Université de Munich 